ON THE RECORD

'SStranger things have happened and craft have been found in unplanned orbits, so we are still hoping."

Louis Friedman, director of the Planetary Society, talks about the disappearance of the solar-sail experiment, Cosmos 1, shortly after its launch on a Russian rocket.

\section{"The Russian navy} is searching for the debris."

Vyacheslav Davidenko, spokesman for Russia's space agency, offers his own assessment of Cosmos T's fate.

\section{SCORECARD}

$\checkmark$ Learned debate A month after The Lancet's scathing attack on the Royal Society, the medical journal graciously adds that it would not go so far as tocall the society a "stuffy, useless beast".

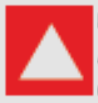

Macho ventures

A French-Jap anese consortium wants to build a jetliner that would travel at mach 5.5 - allowing scientists to zip to their meetings faster than a speeding bullet, literally.

$\nabla$

Political science

The American Civil Liberties Union accuses President Bush of a sustained assault on scientific inquiry, but officials retort thatits study lacks credibility. The same might go for White House climate reports.

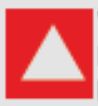

Warm feeling

Doctors deliver the first baby definitely created

from frozen ovarian tissue - a ray of hope for chemotherapy patients.

\section{DATAPOINT}

Percentage of citizens who think the United States can be trusted to protect the gl obal environment:

United

States

Canada

Britain

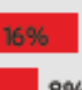

France $6 \%$

Germany $2 \%$

\title{
Japan's university shake-up wins faint praise after first year
}

\section{TOKYO}

Last year, the Japanese government drastically reformed the country's university system. It stripped researchers of fixed benefits, but increased their freedom and independence in the hope of making science more competitive. The government has just released the first survey on what researchers think of the changes, and the results suggest that they are unimpressed.

Before April 2004, the activities of national universities were tightly controlled by the education ministry, but scientists had secure funding, with guaranteed employment for life. Then, in the biggest reforms since the Second World War, universities were given semiautonomous status. Researchers are now freer to collaborate with industry, and university presidents have much more freedom to decide how to spend their budgets. But institutes and researchers alike must earn their money competing to win research grants on merit.

Reformers hoped that the change would reward promising young scientists in a system that has been crowded with unproductive professors (Nature 429, 207-221; 2005). Buthas it worked? To find out, the education ministry polled 2,000 researchers at universities, and at the public research institutes that have been going through similar reforms since 2001 .

A spokesman at the education ministry describes the results as "mixed". On the positive side, $44 \%$ of the respondents say they are more willing to present their work outside their own labs in order to build doser relations with the public. And about $30 \%$ say they find it easier to work with private companies.

But many doubt whether the changes will raise overall standards in Japanese research. Only about $10 \%$ agree that research support is better or more flexible, and that research facilities have been improved by the changes. The fact that researchers have to compete for research grants has also not gone down particularly well.

About half of the respondents say that projects that meet specific industrial needs or lie in the government's strategic areas are more likely to be given money. Although this is what reformers were hoping to achieve, it leads many to express concern that important research fields are being ignored.

Kotoku Kurachi, a molecular biologist at the National Institute of Advanced Industrial Science and Technology in Tsukuba, believes that the reforms will help Japan to compete with countries such as the United States. But he says that unless the country's opaque grant system is overhauled, the changes will be in vain. "If we don't establish fair rules, it could get worse than ever."

Ichiko Fuyuno 